\title{
Changes in Piglet Auditory Brainstem Response Amplitudes without Increases in Serum or Cerebrospinal Fluid Neuron-Specific Enolase
}

\author{
THOR W. R. HANSEN, WILLIAM J. CASHORE, AND WILLIAM OH \\ Brown University Program in Medicine, Department of Pediatrics, Women \& Infants' Hospital of Rhode Island, \\ Providence, Rhode Island 02905-2499
}

\begin{abstract}
We studied the relationship between changes in auditory brainstem responses (ABR) and serum and cerebrospinal fluid levels of neuron-specific enolase (NSE) in hyperbilirubinemic 2- to 8-d-old piglets. Infusion of a stabilized solution of bilirubin resulted in serum bilirubin levels of $571.1 \pm 48.8 \mu \mathrm{mol} / \mathrm{L}$ (mean \pm SEM) after $6 \mathrm{~h}$. $A B R$ were obtained at baseline and then hourly until the piglets were killed. We measured peak amplitudes and latencies for waves $I-V$, as well as latency for the post-V trough. Changes in amplitudes and latencies were analyzed as slopes because of heterogeneous variances. Over time, a significant reduction was observed in peak II-V amplitudes of bilirubin-infused piglets, but not in those of corresponding controls. No change was observed in latencies. NSE was analyzed by RIA. Serum NSE remained stable throughout the experiment (means 5.1-6.6 $\mu \mathrm{g} / \mathrm{L}$ ) and did not differ between the groups. Cerebrospinal fluid NSE values also remained stable, and no differences that could be ascribed to hyperbilirubinemia were detected. We conclude that hyperbilirubinemia induced significant changes in piglet $A B R$ amplitudes without concomitant evidence of severe neuronal compromise, as might have been indicated by significant increases in serum and/or cerebrospinal fluid NSE levels. This provides further support to the clinical impression that early ABR changes during hyperbilirubinemia may be reversible. (Pediatr Res 32: 524-529, 1992)
\end{abstract}

\section{Abbreviations}

ABR, auditory brainstem response

NSE, neuron-specific enolase

CSF, cerebrospinal fluid

$\mathrm{dB}$, decibel

Hyperbilirubinemia is one of the most common conditions observed in the newborn nursery (1). The most serious complication of neonatal jaundice is kernicterus, which may result in death or in severe neurodevelopmental sequelae (2-5). Kernicterus was initially described in term infants whose jaundice was caused by $\mathrm{Rh}$-immunization (6-10). Although kernicterus from this cause is now rare in Western industrialized countries, bili-

Received July 31, 1991; accepted June 23, 1992.

Correspondence and reprint requests: William Oh, M.D., Department of Pediatrics, Women \& Infants' Hospital of Rhode Island, 101 Dudley St., Providence, RI 02905-2499.

Supported in part by grants from The Norwegian Research Council for Science and the Humanities, Distriktslege Johan Widding Heiberg Cammermeyer's Legacy, Professor dr.med. Martin Seip's Fund, Nathalia \& Knut Juul Christiansens Foundation, A/S Freia Chocolade Fabriks Medical Fund, Konsul Cato N. B. Aalls Legacy, and Dr. A. Malthes Legacy for Internal Medicine (T.W.R.H.). W.J.C. is the recipient of NIH Grant No. R01 HD 22310 rubin continues to be found at autopsy in the brains of babies who died from complications of prematurity or other severe illness in the neonatal period $(11,12)$. In some of these babies, serum bilirubin levels were never very high by the standards that ordinarily guide decisions to treat jaundice.

Furthermore, it is known that many babies who survive prematurity and/or severe illness in the neonatal period have neurologic and/or developmental sequelae (13-15). Though it has been difficult in some retrospective clinical studies to demonstrate a clear relationship between neonatal jaundice and subsequent sequelae (16-18), other studies are more suggestive $(4,19-$ 22). Sick newborns are exposed to many potentially noxious influences, and it is not surprising that it should be difficult to determine the relative importance of each to the eventual outcome. Also, as the newborn brain has a considerable capacity to compensate for lost neurons, neuronal loss must be quite extensive before the sequelae would be detectable by the diagnostic methods currently at our disposal.

It is possible that the effects of bilirubin on neuronal excitability may be transitory. Such effects have been observed both in vivo and in vitro (23-27). The $\mathrm{ABR}$ has recently been used to study jaundiced newborns, and some of these studies suggest that the changes observed during hyperbilirubinemia are reversible $(23,24,26)$. However, the mechanism for the effects of hyperbilirubinemia on the ABR has not been delineated.

The ABR is an expression of activity in a group of neurons. Apparent reversibility of neurophysiologic changes in this group of neurons does not necessarily rule out permanent damage to individual neurons. Thus, it is of interest to study whether changes in the ABR, as seen in hyperbilirubinemia, are accompanied by evidence of permanent damage to the neurons.

Enolase is one of the glycolytic enzymes and is a dimer of three subunits: $\alpha, \beta$, and $\gamma(28)$. The $\gamma$-subunit has been found to be identical to 14-3-2 protein, one of the nervous systemspecific proteins (29). In the CNS, this specific protein is mainly localized in neuronal cells as $\alpha \gamma$ and $\gamma \gamma$ enolases, so called NSE (30). NSE has been shown to be an indirect marker of the degree of neuronal damage in neurologic disease $(31,32)$. Finally, it has been shown that this protein appears in the plasma and CSF of jaundiced rats (33).

The effects of bilirubin on the brain may include increased membrane permeability in the neurons (34-37). Increased permeability to small molecules such as ions, resulting in changes in the membrane potential, is likely to precede leakage of larger molecules such as proteins from the neurons. Therefore, to the extent that changes in the $A B R$ in jaundiced, newborn piglets represent changes in membrane permeability, such changes ought to precede increases of NSE concentration in the CSF and/or serum, the latter indicating leakage of proteins from more severely compromised neurons. 


\section{MATERIALS AND METHODS}

The study protocol was approved by our institutional animal care committee. Newborn piglets (1-3 d old) were purchased from Parsons Farms, Hadley, MA, weaned from the sow, and kept in an animal care facility for $1-5 \mathrm{~d}$ before the study. At the time of the study, they weighed $1621 \pm 315 \mathrm{~g}$ (mean \pm SD) and were $4.5 \pm 2.4 \mathrm{~d}$ old. On the day of the study, each piglet was anesthetized with ketamine $10 \mathrm{mg} / \mathrm{kg}$ intramuscularly plus inhaled nitrous oxide $\left(60 \% \mathrm{~N}_{2} \mathrm{O} / 40 \% \mathrm{O}_{2}\right)$, supplemented with $1 \%$ lidocaine local anesthesia. Polyethylene catheters were placed in the left femoral artery and vein and advanced into the abdominal vessels to allow for infusion and blood sampling. A 19-gauge teflon catheter was placed in the lumbar subdural space through a 17-gauge Tuohy-type epidural needle (The Kendall Company, Boston, MA) to allow repeated sampling of CSF. Subcutaneous needle electrodes were placed behind the right (active) and left (reference) ears and in the occipital (ground) area and secured with sutures, and foam rubber-padded earphones (Cadwell Insert Headphones, Cadwell Co., Kennewick, WA) were taped into both ears. A rectal probe was inserted for continuous temperature monitoring, and the output of an overhead radiant warmer was adjusted to maintain the temperature in the $38.5-39.5^{\circ} \mathrm{C}$ range. The piglet was placed in a dark box large enough to accommodate the animal without permitting it to turn around and allowed a 1 -h recovery period. For purposes of sedation, the piglet continued to breathe a $\mathrm{N}_{2} \mathrm{O} / \mathrm{O}_{2}$ mixture as described above throughout the recovery period as well as the entire study period. Additional sedation was provided by diazepam $0.1-0.2 \mathrm{mg}$ i.v. as required to avoid movement artifacts in the ABR.

At the start of the experiment, an ABR was obtained from the right ear using a Cadwell Quantum 84 evoked potential recording/averaging machine (Cadwell Laboratories, Inc., Kennewick, WA) delivering single rarified square wave clicks of $100 \mu \mathrm{s}$ duration at $70 \mathrm{~dB}$, normal hearing level, at a rate of 11.1 clicks/ s. Cadwell insert headphones ( $300 \mathrm{ohms}$ ), supplied by the manufacturer, were used to deliver the click signals. They had a stable output between 100 and $4000 \mathrm{~Hz}$, a drive voltage of $0.49 \mathrm{~V}$ root mean square, peak output of $104.3 \mathrm{~dB}$ at $1000 \mathrm{~Hz}$, and total harmonic distortion of $2.8 \%$ at $500 \mathrm{~Hz}$ and $118.5 \mathrm{~dB}$. Low-cut and high-cut filters were set at 100 and $3000 \mathrm{~Hz}$, respectively. The headphones were secured and shielded with foam rubber plugs and taped into each ear. The responses to 1000 consecutive clicks were averaged, and the peak amplitudes $(\mu \mathrm{V})$ and latencies (ms) of waves I-V were measured using the on-screen cursor lines, according to the criteria of Jewett and Williston (38) to define the peaks. In each tracing, vertex positivity was upward. Baseline blood samples were drawn from the femoral artery catheter, and a baseline CSF sample was obtained from the subdural catheter.

Bilirubin (Sigma Chemical Co., St. Louis, MO) was dissolved in $0.1 \mathrm{~N} \mathrm{NaOH}$, stabilized with BSA (molar ratio bilirubin:albumin = 14), and diluted with $0.055 \mathrm{M}$ phosphate buffer, $\mathrm{pH} 7.4$ (final $\mathrm{pH} \approx 8$ ). Bilirubin was then infused into the femoral vein catheter at a rate of $7 \mathrm{mg} / \mathrm{kg} / \mathrm{min}$ for $5 \mathrm{~min}$, after which the infusion was continued at $25 \mathrm{mg} / \mathrm{kg} / \mathrm{h}$ for $6 \mathrm{~h}$. Control animals were infused with bilirubin-free solvent. Sulfisoxazole $80 \mathrm{mg} / \mathrm{kg}$ (Gantrisin, Hoffman-LaRoche Inc., Nutley, NJ) was given i.v. at 0.5 and $2.5 \mathrm{~h}$. The experiments were carried out under red light conditions to retard photodecomposition of the bilirubin solution. ABR and blood as well as CSF samples were obtained hourly. Serum bilirubin was measured with a diazo method (39). Serum unbound bilirubin was estimated with the peroxidase method (40). Serum albumin was measured with the bromocresol green method (41). NSE was measured with a RIA (Pharmacia, Uppsala, Sweden). Hematocrit was measured using microhematocrit tubes. Blood gases and $\mathrm{pH}$ were measured using a Corning $178 \mathrm{pH} /$ blood gas analyzer (Ciba Corning Diagnostics Corp., Medfield, MA).

At the conclusion of the experiment, the animals were killed with a bolus injection of sodium pentobarbital. In the bilirubininfused animals, catheters were placed in both common carotid arteries, the jugular veins were opened, and the brain was flushed in situ with cold saline until the effluent from the jugular veins was clear. A piece of frontal cortex, vermis cerebelli, and four sections of the medulla (cochlear nucleus, superior olive, lateral lemniscus, and inferior colliculus) were dissected out. The bilirubin content of the brain tissue was estimated by acid chloroform extraction followed by diazotization (42).

Data were analyzed with $t$ tests and two-way analysis of variance. However, to reduce the effect of heterogeneous variances of the ABR measurements, the changes over time in peak amplitudes and latencies were calculated as a slope $(\mu \mathrm{V} / \mathrm{h}$ and $\mathrm{ms} / \mathrm{h}$ ) using the program LINEFIT (43). The null hypothesis of no change over time (slope $=0$ ) was tested by calculating confidence intervals, and the null hypothesis of no difference between bilirubin-infused animals and controls was tested with unpaired $t$ tests. Statistical significance was taken as $p<0.05$.

\section{RESULTS}

The results of the blood and serum analyses are presented in Table 1. Unbound bilirubin is not detectable in nonjaundiced subjects and was therefore not analyzed in the control piglets. As expected, the serum albumin levels increased during the experiment because of the albumin in the infusate. For fortuitous reasons, the control piglets had lower hematocrit values than the bilirubin-infused animals. This is unlikely to have influenced the final results. The blood $\mathrm{pH}$ changed over time, mainly because a metabolic acidosis developed at $6 \mathrm{~h}$ in the bilirubin-infused piglets. The values for $\mathrm{PCO}_{2}$ and $\mathrm{PO}_{2}$ did not change over time and did not differ between the groups. These data are therefore not reported.

Values for peak amplitudes and latencies of the piglet $A B R$, based on the baseline ABR in all study animals, are presented in Table 2. As will be seen, it was possible to consistently record values for five peaks plus the trough after peak $V$. To our knowledge, this is the first time ABR values have been reported for piglets.

The results of the analyses of changes in ABR peak amplitudes are presented in Table 3 . The slopes of the changes in ABR peak amplitudes were negative for all bilirubin-infused piglets (although not significantly different from 0 for peak I), meaning that the ABR peak amplitudes were reduced with time of exposure to hyperbilirubinemia. Plotting of the data showed that the slopes were linear, and extrapolation of the slope indicated that isoelectricity would have been reached after 10 to $12 \mathrm{~h}$ if the same trend had continued. With the exception of peak $I$, there was no significant change over time in the amplitudes for the control piglets. Although the slope of the peak I amplitude changes was negative for the control piglets, there was no significant difference between the apparent changes for the control piglets and for the bilirubin-infused piglets. The biologic significance of this change is therefore not clear. For ABR peak amplitudes II-V, the differences in slope between bilirubin-infused piglets and controls were significant.

To ascertain the time relationship for appearance of significant reductions in the $A B R$ amplitudes, all amplitudes were recalculated as percentages of the baseline value for that particular peak and subject. The values for control and bilirubin-infused piglets were then contrasted using unpaired $t$ tests for each time point. For peak II, these contrasts were significant from $5 \mathrm{~h}$ on; for peak III, they were significant from $3 \mathrm{~h}$ on; for peak IV, none of the contrasts were significant because of large variances; and for peak $\mathrm{V}$, the contrasts were significant from $2 \mathrm{~h}$ on.

The results of the analyses of changes in ABR peak latencies are presented in Table 4. As will be seen, there were no significant changes over time in either the bilirubin-infused piglets or the controls, and there were no significant differences between the groups. However, the slopes for all latencies except trough were 
Table 1. Results of blood/serum analyses in hyperbilirubinemic and control piglets

\begin{tabular}{|c|c|c|c|c|c|c|c|c|c|c|c|c|c|c|}
\hline \multirow[b]{3}{*}{ Parameter } & \multirow[b]{3}{*}{ Group* } & \multirow{2}{*}{\multicolumn{7}{|c|}{ Sampling time $(\mathrm{h}) \dagger$}} & \multicolumn{6}{|c|}{ Effects } \\
\hline & & & & & & & & & \multicolumn{2}{|c|}{ Time } & \multicolumn{2}{|c|}{ Group } & \multicolumn{2}{|c|}{ Group $\times$ time } \\
\hline & & 0 & 1 & 2 & 3 & 4 & 5 & 6 & $F \ddagger$ & $p$ & $F$ & $p$ & $F$ & $p$ \\
\hline \multirow[t]{6}{*}{ Bilirubin $(\mu \mathrm{mol} / \mathrm{L})$} & $\mathrm{B}$ & & & & & & & & & & & & & \\
\hline & Mean & 4.1 & 263.3 & 342.7 & 403.4 & 453.7 & 513.3 & 571.1 & & & & & & \\
\hline & SEM & 1.8 & 17.6 & 28.4 & 36.4 & 39.3 & 31.9 & 48.8 & 33.6 & $<0.0001$ & 739.9 & $<0.0001$ & 28.6 & $<0.0001$ \\
\hline & $\mathrm{C}$ & & & & & & & & & & & & & \\
\hline & Mean & 0.3 & 1.8 & 2.7 & 0.7 & 1.2 & 1.7 & 1.3 & & & & & & \\
\hline & SEM & 0.3 & 0.9 & 1.9 & 0.4 & 0.4 & 0.8 & 0.4 & & & & & & \\
\hline \multirow{3}{*}{$\begin{array}{l}\text { Unbound bilirubin } \\
(\mathrm{nmol} / \mathrm{L})\end{array}$} & $\mathrm{B}$ & & & & & & & & & & & & & \\
\hline & Mean & ND & 10.7 & 11.4 & 42.3 & 62.4 & 66.7 & 65.8 & & & & & & \\
\hline & SEM & & 10.5 & 7.9 & 25.1 & 23.4 & 15.0 & 27.9 & 1.8 & NS & & & & \\
\hline \multirow[t]{6}{*}{ Albumin $(\mathrm{g} / \mathrm{L})$} & $\mathrm{B}$ & & & & & & & & & & & & & \\
\hline & Mean & 14.0 & ND & 16.8 & ND & 20.4 & ND & 23.3 & & & & & & \\
\hline & SEM & 1.6 & & 0.8 & & 1.5 & & 1.6 & 19.7 & $<0.0001$ & 0.0 & NS & 0.9 & NS \\
\hline & $\mathrm{C}$ & & & & & & & & & & & & & \\
\hline & Mean & 12.2 & ND & 19.2 & ND & 21.0 & ND & 22.7 & & & & & & \\
\hline & SEM & 1.0 & & 1.2 & & 1.6 & & 1.1 & & & & & & \\
\hline \multirow[t]{6}{*}{ Hematocrit (\%) } & $\mathrm{B}$ & & & & & & & & & & & & & \\
\hline & Mean & 36.1 & ND & 36.3 & ND & 34.1 & ND & 30.3 & & & & & & \\
\hline & SEM & 1.9 & & 2.1 & & 2.0 & & 2.3 & 2.1 & NS & 15.1 & $<0.005$ & 0.3 & NS \\
\hline & $\mathrm{C}$ & & & & & & & & & & & & & \\
\hline & Mean & 29.2 & ND & 29.7 & ND & 29.0 & ND & 26.8 & & & & & & \\
\hline & SEM & 1.7 & & 1.9 & & 1.9 & & 2.1 & & & & & & \\
\hline \multirow[t]{6}{*}{$\mathrm{pH}$} & $\mathrm{B}$ & & & & & & & & & & & & & \\
\hline & Mean & 7.41 & ND & 7.38 & ND & 7.39 & ND & 7.26 & & & & & & \\
\hline & SEM & 0.01 & & 0.02 & & 0.03 & & 0.06 & 3.2 & $<0.05$ & 0.2 & NS & 2.7 & NS \\
\hline & $\mathrm{C}$ & & & & & & & & & & & & & \\
\hline & Mean & 7.42 & ND & 7.34 & ND & 7.34 & ND & 7.38 & & & & & & \\
\hline & SEM & 0.02 & & 0.04 & & 0.04 & & 0.03 & & & & & & \\
\hline \multirow[t]{6}{*}{ Base excess } & B & & & & & & & & & & & & & \\
\hline & Mean & 0.7 & ND & -0.8 & ND & -1.4 & ND & -7.9 & & & & & & \\
\hline & SEM & 0.9 & & 1.1 & & 1.3 & & 1.4 & 3.7 & $<0.05$ & 54.6 & $<0.0001$ & 9.2 & $<0.0001$ \\
\hline & C & & & & & & & & & & & & & \\
\hline & Mean & 3.5 & ND & 2.4 & ND & 3.5 & ND & 5.4 & & & & & & \\
\hline & SEM & 1.3 & & 1.0 & & 1.0 & & 0.8 & & & & & & \\
\hline
\end{tabular}

* $\mathrm{B}$, bilirubin $(n=7)$; C, controls $(n=6)$.

$\dagger \mathrm{ND}$, not determined.

¥ Two-way analysis of variance.

Table 2. Baseline means and $S D$ for piglet $A B R^{*}$

\begin{tabular}{lcc}
\hline & $\begin{array}{c}\text { Amplitude } \\
(\mu \mathrm{V})\end{array}$ & $\begin{array}{c}\text { Latency } \\
(\mathrm{ms})\end{array}$ \\
\hline Peak I & $1.02 \pm 0.41$ & $1.66 \pm 0.08$ \\
Peak II & $0.80 \pm 0.40$ & $2.24 \pm 0.15$ \\
Peak III & $0.57 \pm 0.40$ & $3.38 \pm 0.14$ \\
Peak IV & $0.39 \pm 0.25$ & $4.36 \pm 0.19$ \\
Peak V & $0.32 \pm 0.16$ & $5.46 \pm 0.35$ \\
Trough & Not applicable & $5.96 \pm 0.35$ \\
\hline
\end{tabular}

$$
* n=13 \text {. }
$$

positive, indicating a slight increase in latencies over time. The data were therefore recalculated as percentages of baseline value and reanalyzed using analysis of variance. There were no significant group, time, or group-by-time interaction effects. The I-II, I-III, I-IV, I-V, and I-trough interwave intervals were measured, recalculated as percentages of baseline value, and analyzed using analysis of variance. There were no significant group, time, or group-by-time interaction effects. Examples of piglet ABR tracings illustrating the changes between 0 and $6 \mathrm{~h}$ during hyperbilirubinemia are shown in Figure 1.
Table 3. Changes in ABR peak amplitudes analyzed as slope

\begin{tabular}{|c|c|c|c|c|c|}
\hline \multirow[b]{2}{*}{ Peak } & \multirow[b]{2}{*}{ Group* } & \multirow[b]{2}{*}{ Slope $(\mu \mathrm{V} / \mathrm{h}) \dagger$} & \multirow{2}{*}{$\begin{array}{c}\text { Slope } \\
\text { different } \\
\text { from } 0 \\
\end{array}$} & \multicolumn{2}{|c|}{$\begin{array}{l}\text { Intergroup } \\
\text { differences } \ddagger\end{array}$} \\
\hline & & & & $t$ & $p$ \\
\hline 1 & $\begin{array}{l}\mathrm{B} \\
\mathrm{C}\end{array}$ & $\begin{array}{l}-0.0767 \pm 0.0403 \\
-0.0511 \pm 0.0248\end{array}$ & $\begin{array}{c}\text { No } \\
p<0.05\end{array}$ & -0.5181 & NS \\
\hline 2 & $\begin{array}{l}\mathrm{B} \\
\mathrm{C}\end{array}$ & $\begin{array}{r}-0.0788 \pm 0.0311 \\
0.0177 \pm 0.0171\end{array}$ & $\begin{array}{c}p<0.05 \\
\text { No }\end{array}$ & -2.5884 & $<0.05$ \\
\hline 3 & $\begin{array}{l}\mathrm{B} \\
\mathrm{C}\end{array}$ & $\begin{array}{r}-0.0740 \pm 0.0224 \\
0.0104 \pm 0.0115\end{array}$ & $\begin{array}{c}p<0.01 \\
\quad \text { No }\end{array}$ & -3.1795 & $<0.01$ \\
\hline 4 & $\begin{array}{l}\text { B } \\
\text { C }\end{array}$ & $\begin{array}{r}-0.0476 \pm 0.0182 \\
0.0059 \pm 0.0123\end{array}$ & $\begin{array}{c}p<0.05 \\
\text { No }\end{array}$ & -2.3480 & $<0.01$ \\
\hline 5 & $\begin{array}{l}\mathrm{B} \\
\mathrm{C}\end{array}$ & $\begin{array}{r}-0.0361 \pm 0.0093 \\
0.0136 \pm 0.0075\end{array}$ & $\begin{array}{c}p<0.001 \\
\text { No }\end{array}$ & -4.062 & $<0.01$ \\
\hline
\end{tabular}

$* \mathrm{~B}$, bilirubin-infused $(n=7)$; C, controls $(n=6)$.

$\dagger$ Results are presented as mean \pm SEM.

$\ddagger$ All $p$ values are two-tailed. 
Table 4. Changes in ABR peak latencies analyzed as slope

\begin{tabular}{|c|c|c|c|c|c|}
\hline \multirow[b]{2}{*}{ Peak } & \multirow[b]{2}{*}{ Group* } & \multirow[b]{2}{*}{ Slope $(\mu \mathrm{V} / \mathrm{h}) \dagger$} & \multirow{2}{*}{$\begin{array}{c}\text { Slope } \\
\text { different } \\
\text { from } 0\end{array}$} & \multicolumn{2}{|c|}{$\begin{array}{c}\text { Intergroup } \\
\text { differencesł }\end{array}$} \\
\hline & & & & $t$ & $p$ \\
\hline 1 & $\begin{array}{l}\mathrm{B} \\
\mathrm{C}\end{array}$ & $\begin{array}{r}0.0031 \pm 0.0063 \\
-0.0064 \pm 0.0044\end{array}$ & $\begin{array}{l}\text { No } \\
\text { No }\end{array}$ & 1.1945 & NS \\
\hline 2 & $\begin{array}{l}\mathrm{B} \\
\mathrm{C}\end{array}$ & $\begin{array}{r}0.0087 \pm 0.0147 \\
-0.0199 \pm 0.0109\end{array}$ & $\begin{array}{l}\text { No } \\
\text { No }\end{array}$ & 1.5165 & NS \\
\hline 3 & $\begin{array}{l}\mathrm{B} \\
\mathrm{C}\end{array}$ & $\begin{array}{r}0.0153 \pm 0.0123 \\
-0.0067 \pm 0.0120\end{array}$ & $\begin{array}{l}\text { No } \\
\text { No }\end{array}$ & 1.2694 & NS \\
\hline 4 & $\begin{array}{l}\mathrm{B} \\
\mathrm{C}\end{array}$ & $\begin{array}{r}0.0317 \pm 0.0341 \\
-0.0009 \pm 0.0164\end{array}$ & $\begin{array}{l}\text { No } \\
\text { No }\end{array}$ & 0.8147 & NS \\
\hline 5 & $\begin{array}{l}\mathrm{B} \\
\mathrm{C}\end{array}$ & $\begin{array}{r}0.0102 \pm 0.0281 \\
-0.0268 \pm 0.0201\end{array}$ & $\begin{array}{l}\text { No } \\
\text { No }\end{array}$ & 1.0365 & NS \\
\hline Trough & $\begin{array}{l}\mathrm{B} \\
\mathrm{C}\end{array}$ & $\begin{array}{l}-0.0082 \pm 0.0348 \\
-0.0107 \pm 0.0240\end{array}$ & $\begin{array}{l}\text { No } \\
\text { No }\end{array}$ & 0.0571 & NS \\
\hline
\end{tabular}

$* \mathrm{~B}$, bilirubin-infused $(n=7)$; , controls $(n=6)$.

$\dagger$ Results are presented as mean \pm SEM

$\Varangle$ All $p$ values are two-tailed.

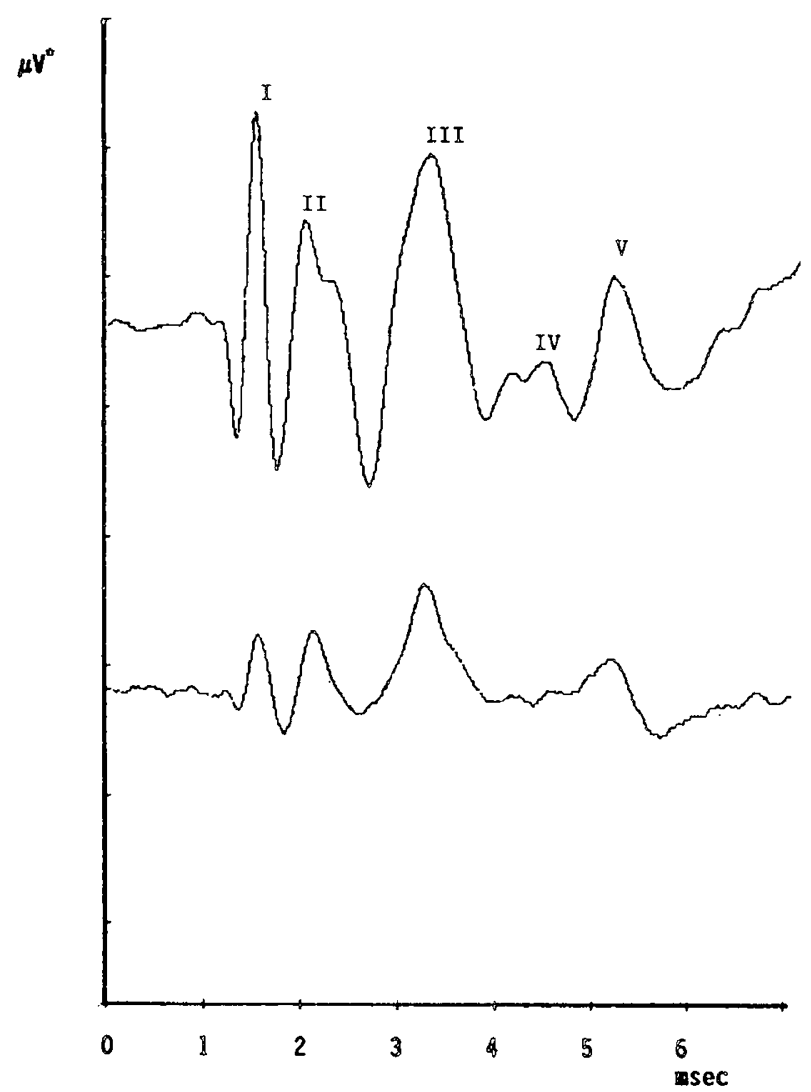

Fig. 1. Effects of hyperbilirubinemia on piglet ABR. Each division on the $y$-axis $=0.5 \mu \mathrm{V}$; the vertical positions of the tracings are arbitrary. Vertex positivity is upward. Upper tracing is baseline, before bilirubin infusion; lower tracing was obtained after $6 \mathrm{~h}$ of hyperbilirubinemia.

The results of brain bilirubin extractions from medulla, cerebral cortex, and vermis cerebelli are shown in Table 5. Though it appeared that tissue bilirubin concentrations were higher in the medulla, these differences were not significant. In cats, peak $I$ in the $A B R$ is thought to have its anatomical correlate in the auditory nerve, peak II in the cochlear nucleus, peak III in the superior olive, peak IV in the lateral lemniscus, and peak V in the inferior colliculus (44). Data are not known for piglets, and correlation analyses of cochlear nucleus bilirubin concentration
Table 5. Brain bilirubin values in bilirubin-infused piglets*

\begin{tabular}{lc}
\hline \multicolumn{1}{c}{ Region } & $\begin{array}{c}\text { Brain bilirubin } \\
(\mu \mathrm{g} / \mathrm{g} \pm \mathrm{SEM})\end{array}$ \\
\hline Cochlear nucleus & $18.3 \pm 5.2$ \\
Superior olive & $17.4 \pm 3.9$ \\
Lateral lemniscus & $16.2 \pm 3.5$ \\
Inferior colliculus & $13.6 \pm 3.4$ \\
Cerebral cortex & $10.8 \pm 3.2$ \\
Vermis cerebelli & $12.1 \pm 3.9$ \\
\hline
\end{tabular}

$*_{n}=7$.

with peak II amplitude at $6 \mathrm{~h}$, superior olive bilirubin concentrations with peak III amplitude at $6 \mathrm{~h}$, lateral lemniscus bilirubin concentrations with peak IV amplitude at $6 \mathrm{~h}$, and inferior colliculus bilirubin concentrations with peak $\mathrm{V}$ amplitude at $6 \mathrm{~h}$ did not yield any significant correlations (data not presented). Further studies are needed to 1 ) ascertain the anatomical correlates of the various ABR peaks in piglets, and 2) determine the relationship, if any, between brain bilirubin levels and amplitude reductions.

Finally, the results of the analyses of serum and CSF NSE are presented in Table 6. Normal levels of serum and CSF NSE are not known in piglets, but the levels of serum NSE remained within what is thought to be a normal range for healthy humans throughout the duration of the experiment and did not change significantly over time, nor did they differ between the groups. The levels of NSE in CSF were somewhat higher, but generally within what appears to be a normal range for rats $(<17 \mu \mathrm{g} / \mathrm{L})$ (45). For reasons that appear fortuitous, the CSF NSE levels were significantly higher in the controls than in the bilirubin-infused piglets.

\section{DISCUSSION}

Our results show that hyperbilirubinemia decreases peak amplitudes in the piglet ABR. Similar effects of hyperbilirubinemia on the ABR have been demonstrated in rats (46), but Shapiro (47) also observed increased latencies for waves II and III, as well as increased I-II and I-III interwave intervals. In human neonates, as well as in rhesus monkeys, both reduction of amplitudes and prolongation of latencies have been observed $(23-25,48-50)$. Our results provide additional evidence that bilirubin in the brain influences neuronal function, and this effect occurs in several species. The newborn piglet appears to be a useful model for bilirubin neurotoxicity in the newborn period.

It is not clear whether bilirubin-induced effects on the ABR are due to changes in neuronal permeability or to inhibition of synaptic function by other mechanisms, such as neurotransmitter release. There is experimental evidence to suggest that bilirubin effects on neurons, at least in vitro, may include both increased membrane permeability (34-37) and inhibition of the biochemical mechanisms underlying neurotransmitter release $(51)$. The lack of increase of NSE concentrations in serum and CSF in the present study is compatible with both of these mechanisms. If increased membrane permeability is indeed the mechanism underlying bilirubin effects on the $A B R$, the findings presented herein support our hypothesis that ABR changes would appear before the concentration of NSE in serum and/or CSF began to increase. On the other hand, if hyperbilirubinemia affects the $\mathrm{ABR}$ through the neurotransmitter release process rather than by increasing membrane permeability, NSE concentrations in serum and/or CSF might not increase at all. Regardless of the mechanism involved, the results reported here are compatible with clinical impressions of reversibility of ABR changes in jaundiced newborns.

The increases in NSE detected in homozygous Gunn rats by Semba and Kato (33) were primarily seen in rats with severe kernicterus induced by the injection of a displacing agent (bucolome) $16-18 \mathrm{~h}$ before they were killed. In these, CSF NSE levels 
Table 6. Serum and CSF NSE in hyperbilirubinemic and control piglets

\begin{tabular}{|c|c|c|c|c|c|c|c|c|c|c|c|c|c|c|}
\hline \multirow[b]{3}{*}{ Source } & \multirow[b]{3}{*}{ Group* } & \multirow{2}{*}{\multicolumn{7}{|c|}{ Sampling time $(\mathrm{h}) \dagger$}} & \multicolumn{6}{|c|}{ Effect } \\
\hline & & & & & & & & & \multicolumn{2}{|c|}{ Time } & \multicolumn{2}{|c|}{ Group } & \multicolumn{2}{|c|}{$\begin{array}{l}\text { Group } \\
\times \text { time }\end{array}$} \\
\hline & & 0 & 1 & 2 & 3 & 4 & 5 & 6 & $F$ & $p$ & $F$ & $p$ & $F$ & $p$ \\
\hline \multirow[t]{6}{*}{ Serum } & B & & & & & & & & & & & & & \\
\hline & Mean & 6.0 & 5.6 & 5.6 & 6.6 & 6.4 & 5.5 & 5.1 & & & & & & \\
\hline & SEM & 0.4 & 0.3 & 0.7 & 1.1 & 0.7 & 0.6 & 1.0 & 0.2 & NS & 0.3 & NS & 0.4 & NS \\
\hline & $\mathrm{C}$ & & & & & & & & & & & & & \\
\hline & Mean & 5.8 & 6.1 & 5.9 & 5.3 & 5.2 & 5.3 & 5.6 & & & & & & \\
\hline & SEM & 0.8 & 1.0 & 1.1 & 0.8 & 1.2 & 0.7 & 1.1 & & & & & & \\
\hline \multirow[t]{6}{*}{ CSF } & $\mathrm{B}$ & & & & & & & & & & & & & \\
\hline & Mean & 14.4 & 14.8 & 11.1 & 11.1 & 10.9 & 11.3 & 10.8 & & & & & & \\
\hline & SEM & 2.5 & 2.8 & 1.4 & 1.7 & 1.2 & 1.6 & 1.5 & 0.7 & NS & 4.9 & $<0.05$ & 0.1 & NS \\
\hline & $\mathrm{C}$ & & & & & & & & & & & & & \\
\hline & Mean & 21.9 & 17.8 & 15.8 & 13.6 & 14.4 & 14.5 & 15.9 & & & & & & \\
\hline & SEM & 6.1 & 5.5 & 4.7 & 4.9 & 4.0 & 4.6 & 5.1 & & & & & & \\
\hline
\end{tabular}

$* \mathrm{~B}$, bilirubin-infused $(n=7)$; c, controls $(n=6)$.

$\dagger$ Results are in $\mu \mathrm{g} / \mathrm{L}$.

were 35 -fold higher than in controls and were accompanied by histologic evidence of severe brain damage. In rats with lesser degrees of brain damage as shown by early degenerative changes in the Purkinje cells, CSF NSE levels were elevated to three to four times control levels.

The time of exposure/insult is clearly relevant. In the study by Semba and Kato (33), no attempts were made to measure NSE until 16-18 h after the injection of bucolome. However, as the levels of NSE in CSF were increased 35-fold, it would appear likely that significant increases in CSF NSE concentration were detectable earlier. In support of this, Steinberg et al. (45) found NSE levels of $\approx 100 \mu \mathrm{g} / \mathrm{L}$ in rat CSF $6 \mathrm{~h}$ after injecting kainic acid in the striatum. The experiments reported herein used much higher serum bilirubin concentrations than those found in homozygous Gunn rats, as well as repeated injections of a displacing substance, resulting in higher brain bilirubin concentrations than one might expect to find in homozygous Gunn rats. Whether the insult caused by this type of manipulation equates to that of a more prolonged but less intense hyperbilirubinemia typically seen in jaundiced neonates needs to be studied further. The fact that some studies have reported effects on amplitudes, others primarily on latencies, and some on both, is another indication of the need for further studies in this area.

Thus, the studies reported herein showed that hyperbilirubinemia in piglets resulted in significant reductions in ABR peak amplitudes $(\approx 50 \%$ reduction after $6 \mathrm{~h})$, without increases in serum or CSF NSE concentrations. This suggests that changes in the ABR may occur without severe compromise of neuronal membrane integrity and provides further support to the idea that early ABR changes during hyperbilirubinemia may be reversible.

Acknowledgment. The authors thank Nelda Kilguss for excellent laboratory assistance.

\section{REFERENCES}

1. Maisels MJ 1981 Neonatal jaundice. In: Avery GB (ed) Neonatology. JB Lippincott Co, Philadelphia, pp 473-544

2. Schmorl G 1904 Zur Kenntnis des Ikterus Neonatorum. Verh Dtsch Ges Pathol 6:109-115

3. Byers RK, Paine RS, Crothers B 1955 Extrapyramidal cerebral palsy with hearing loss following erythroblastosis. Pediatrics 15:248-254

4. Perlstein MA 1960 The late clinical syndrome of posticteric encephalopathy. Pediatr Clin North Am 7:665-687

5. Hyman CB, Keaster J, Hanson V, Harris I, Sedgwick R, Wursten H, Wright AR 1969 CNS abnormalities after neonatal hemolytic disease or hyperbilirubinemia. A prospective study of 405 patients. Am J Dis Child 117:395405

6. Docter JM 1945 Kernicterus: neurological sequelae of erythroblastosis fetalis. J Pediatr 27:327-334
7. Lande L 1948 Clinical signs and development of survivors of kernicterus due to Rh sensitization. J Pediatr 32:693-705

8. Küster F, Krings H 1950 Blood destruction and cerebral damage in haemolytic disease of the newborn. Lancet 1:979

9. Gerrard J 1952 Kernicterus. Brain 75:526-570

10. Mollison PL, Cutbush M 1954 Haemolytic disease of the newborn. In: Gardner $\mathrm{D}$ (ed) Recent Advances in Pediatrics. Churchill Ltd, London, pp 110-132

11. Barmada MA, Moossy $J 1982$ Neonatal kernicterus and pontosubicular necrosis. J Neuropathol Exp Neurol 41:347A(abstr)

12. Ahdab-Barmada M, Moossy J 1984 The neuropathology of kernicterus in the premature neonate: diagnostic problems. J Neuropathol Exp Neurol 43:4556

13. Rubin RA, Rosenblatt C, Balow B 1973 Psychological and educational sequelae of prematurity. Pediatrics 52:352-363

14. Francis-Williams J, Davies PA 1974 Very low birthweight and later intelligence. Dev Med Child Neurol 16:709-728

15. Michelsson K, Noronen M 1983 Neurological, psychological and articulatory impairment in five-year-old children with a birthweight of $2000 \mathrm{~g}$ or less. Eur J Pediatr 141:96-100

16. Shiller JG, Silverman WA 1960 The lack of association between hyperbilirubinemia and brain damage of prematurity. Am J Dis Child 100:496-500

17. Shiller JG, Silverman WA 1961 "Uncomplicated" hyperbilirubinemia of prematurity. The lack of association with neurologic deficit at 3 years of age. Am J Dis Child 101:587-592

18. Wishingrad L, Cornblath M, Takakuwa T, Rozenfeld IM, Elegant LD, Kaufman A, Lassers E, Klein RI 1965 Studies of non-hemolytic hyperbilirubinemia in premature infants. I. Prospective randomized selection for exchange transfusion with observations on the levels of serum bilirubin with and without exchange transfusion and neurologic evaluations one year after birth Pediatrics $36: 162-172$

19. Day R, Haines MS 1954 Intelligence quotients of children recovered from erythroblastosis fetalis since the introduction of exchange transfusion. Pediatrics 13:333-338

20. Odell GB, Storey GNB, Rosenberg LA 1970 Studies in kernicterus. III. The saturation of serum proteins with bilirubin during neonatal life and its relationship to brain damage at five years. J Pediatr 76:12-21

21. Rye HH 1981 Psykologisk unders $\phi k$ kelse av premature barn. En longitudinell unders $\phi$ kelse fra 3 år til ungdomsalder. Thesis, Sentralinstituttet for Cerebral Parese, Oslo

22. Nilsen ST, Finne PH, Bergsi $\phi$ P, Stamnes O 1984 Males with neonatal hyperbilirubinemia examined at 18 years of age. Acta Paediatr Scand 73:176180

23. Perlman M, Fainmesser P, Sohmer H, Tamari H, Wax Y, Pevsmer B 1983 Auditory nerve-brainstem evoked responses in hyperbilirubinemic neonates. Pediatrics 72:658-664

24. Nwaesei CG, Van Aerde J, Boyden M, Perlman M 1984 Changes in auditory brainstem responses in hyperbilirubinemic infants before and after exchange transfusion. Pediatrics 74:800-803

25. Ahlfors CE, Bennett SH, Shoemaker CT, Ellis WG, Davis SL, Wennberg RP Goetzman BW 1986 Changes in the auditory brainstem response associated with intravenous infusion of unconjugated bilirubin into infant rhesus monkeys. Pediatr Res 20:511-515

26. Chin KC, Taylor MJ, Perlman M 1985 Improvement in auditory and visua evoked potentials in jaundiced preterm infants after exchange transfusion. Arch Dis Child 60:714-717

27. Hansen TWR, Paulsen O, Gjerstad L, Bratlid D 1988 Short-term exposure to bilirubin reduces synaptic activation in rat transverse hippocampal slices. Pediatr Res 23:453-456

28. Fletcher L, Rider CC, Taylor CB 1976 Enolase isoenzymes III: chromato- 
graphic and immunological characteristics of rat brain enolase. Biochim Biophys Acta 452:245-252

29. Bock E, Dissing J 1975 Determination of enolase activity connected to the brain-specific protein 14-3-2. Scand J Immunol 4(suppl 2):3 I-36

30. Schmechel D, Marangos PJ, Zis AP, Brightman M, Goodwin FK 1987 Brain enolases as specific markers of neuronal and glial cells. Science 199:313-315

31. Scarna H, Delafosses B, Steinberg R, Debilly G, Mandrand B, Keller A, Pujol JF 1982 Neuron-specific enolase as a marker of neuronal lesions during various comas in man. Neurochem Int 4:405-41

32. Royds JA, Davis-Jones GAB, Lewtas NA, Timperley WR, Taylor CB 1983 Enolase isoenzymes in the cerebrospinal fluid of patients with diseases of the nervous system. J Neurol Neurosurg Psychiatry 46:1031-1036

33. Semba R, Kato K 1982 Increased nervous system-specific enolases in rat plasma and cerebrospinal fluid in bilirubin encephalopathy detected in enzyme immunoassays. J Neurochem 39:360-365

34. Cowger ML 1971 Mechanism of bilirubin toxicity on tissue culture cells: factors that affect toxicity, reversibility by albumin, and comparison with other respiratory poisons and surfactants. Biochem Med 5:1-16

35. Mayor Jr F, Diez-Guerra J, Valdivieso F, Mayor F 1986 Effect of bilirubin on the membrane potential of rat brain synaptosomes. J Neurochem 47:363369

36. O'Callaghan A, Duggan PF 1984 Possible biochemical basis for bilirubin neurotoxicity. Biochem Soc Trans 12:483

37. Jew JY, Williams TH 1977 Ultrastructural aspects of bilirubin encephalopathy in cochlear nuclei of the Gunn rat. J Anat 124:599-614

38. Jewett DL, Williston JS 1971 Auditory evoked far fields averaged from the scalp of humans. Brain 94:681-696

39. Martinek RG 1966 Improved micromethod for determination of serum bilirubin. Clin Chim Acta 13:161-170
40. Jacobsen J, Wennberg RP 1974 Determination of unbound bilirubin in the serum of newborns. Clin Chem 20:783-789

41. Doumas BT, Watson WA, Biggs HG 1971 Albumin standards and the measurement of serum albumin with bromocresol green. Clin Chim Acta 31:8796

42. Bratlid D, Winsnes A 1971 Determination of conjugated and unconjugated bilirubin by methods based on direct spectrophotometry and chloroform extraction. A reappraisal. Scand J Clin Lab Invest 28:41-48

43. Barlow RB 1983 Biodata Handling with Microcomputers. Elsevier Science Publishers, Cambridge, UK

44. Buchwald J, Huang C 1975 Far-field acoustic response: origins in the cat. Science 189:382-384

45. Steinberg R, Scarna H, Pujol JF 1984 Neuron-specific enolase in cerebrospinal fluid: a possible indicator of neuronal damage in kainic acid lesions. Neurosci Lett 45:147-150

46. Karplus M, Lee C, Cashore WJ, On W 1988 The effects of brain bilirubin deposition on brain stem evoked responses in rats. Early Hum Dev 16:185194

47. Shapiro SM 1988 Acute brainstem auditory evoked potential abnormalities in jaundiced Gunn rats given sulfonamide. Pediatr Res 23:306-310

48. Lenhardt ML, McArtor R, Bryant B 1984 Effects of neonatal hyperbilirubinemia on the brainstem electric response. J Pediatr 104:281-284

49. Nakamura H, Takada S, Shimabuku R, Matsuo M, Matsuo T, Negishi H 1985 Auditory nerve and brainstem responses in newborn infants with hyperbilirubinemia. Pediatrics 75:703-708

50. Hung K-L 1989 Auditory brainstem responses in patients with neonatal hyperbilirubinemia and bilirubin encephalopathy. Brain Dev 11:297-301

51. Hansen TWR, Bratlid D, Walaas SI 1988 Bilirubin decreases phosphorylation of synapsin I, a synaptic vesicle-associated neuronal phosphoprotein, in intact synaptosomes from rat cerebral cortex. Pediatr Res 23:219-223 